
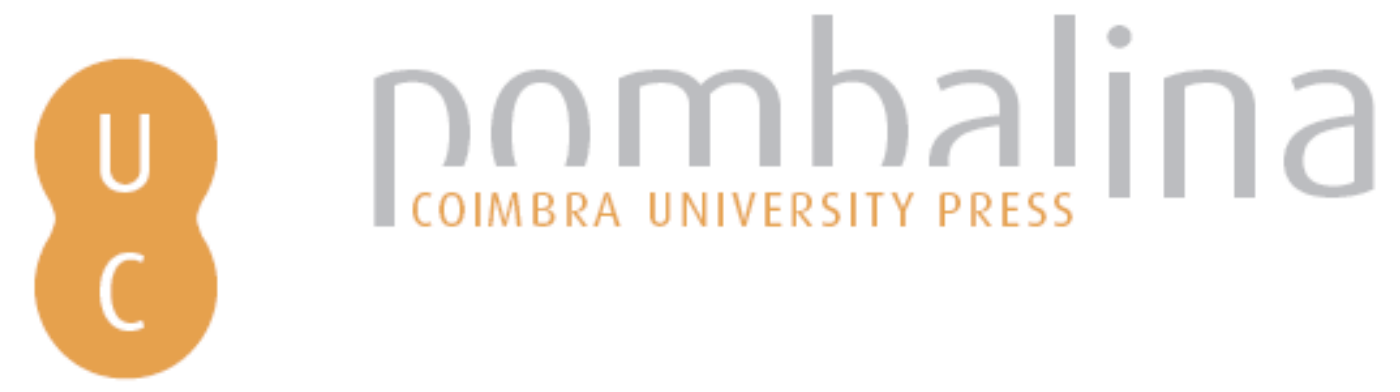

\title{
Integration of geochronologic, paleobotanical and organic matter studies in gondwanan tonstein (Sakmarian, Paraná Basin, Brazil)
}
Autor(es):
Guerra-Sommer, M.; Cazzulo-Klepzig, M.; Mendonça Filho, J. G.;
Degani-Schmidt, I.; Jasper, A.; Menegat, R.; Simas, M. W.

Publicado por: Imprensa da Universidade de Coimbra

URL persistente:

URI:http://hdl.handle.net/10316.2/31401

DOI:

DOI:http://dx.doi.org/10.14195/978-989-26-0534-0_12

Accessed : $\quad$ 26-Apr-2023 11:20:20

A navegação consulta e descarregamento dos títulos inseridos nas Bibliotecas Digitais UC Digitalis, UC Pombalina e UC Impactum, pressupõem a aceitação plena e sem reservas dos Termos e Condições de Uso destas Bibliotecas Digitais, disponíveis em https://digitalis.uc.pt/pt-pt/termos.

Conforme exposto nos referidos Termos e Condições de Uso, o descarregamento de títulos de acesso restrito requer uma licença válida de autorização devendo o utilizador aceder ao(s) documento(s) a partir de um endereço de IP da instituição detentora da supramencionada licença.

Ao utilizador é apenas permitido o descarregamento para uso pessoal, pelo que o emprego do(s) título(s) descarregado(s) para outro fim, designadamente comercial, carece de autorização do respetivo autor ou editor da obra.

Na medida em que todas as obras da UC Digitalis se encontram protegidas pelo Código do Direito de Autor e Direitos Conexos e demais legislação aplicável, toda a cópia, parcial ou total, deste documento, nos casos em que é legalmente admitida, deverá conter ou fazer-se acompanhar por este aviso.

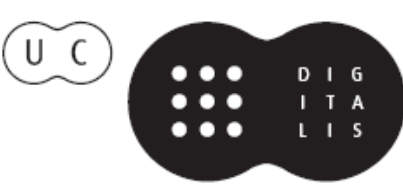





\title{
INTEGRATION OF GEOCHRONOLOGIC, PALEOBOTANICAL AND ORGANIC MATTER STUDIES IN GONDWANAN TONSTEIN (SAKMARIAN, PARANÁ BASIN, BRAZIL)
}

\author{
INTEGRAÇÃO DE ESTUDOS GEOCRONOLÓGICOS, \\ PALEOBOTÂNICOS E DE MATÉRIA ORGÂNICA \\ DISPERSA EM TONSTEIN GONDWÂNICO \\ (SAKMARIANO, BACIA DO PARANÁ, BRASIL)
}

\author{
M. Guerra-Sommer', M. Cazzulo-Klepzig² , J. G. Mendonça Filho³, \\ I. Degani-Schmidt ${ }^{4}$, A. Jasper ${ }^{5}$, R. Menegat ${ }^{6} \&$ M. W. Simas
}

\begin{abstract}
Integration of petrographic, paleobotanic and dispersed organic matter studies, associated to radiometric data (Tuffzir age of 290.15 +2.45/-0.85 Ma) in a tonstein bed interbedded in a coal seam in Faxinal Coalfield (Sakmarian) in Brazilian Southern Paraná Basin (Brazil), evidenced that the rapid volcanic ash fall deposition must be taken into account to interpret the composition, taphonomic process and consequently, preservation of the organic matter which is identified in different stages of deposition of a forested plant-association.
\end{abstract}

1 UFRGS, Instituto de Geociências, Av. Bento Gonçalves, 9500, Cx.P. 15001, 91501-970, Porto Alegre, RS, Brasil; margot.sommer@ufrgs.br

2 UFRGS, Instituto de Geociências, Av. Bento Gonçalves, 9500, Cx.P. 15001, 91501-970, Porto Alegre, RS, Brasil; miriam.klepzig@ufrgs.br

3 UFRJ, Instituto de Geociências, Av. Athos da Silveira Ramos, 274, 21949-900, Rio de Janeiro, RJ, Brasil; graciano@geologia.ufrj.br

4 UFRGS, Instituto de Geociências, Av. Bento Gonçalves, 9500, Cx.P. 15001, 91501-970, Porto Alegre, RS, Brasil; degani.schmidt@ufrgs.br

5 UNIVATES, Rua Avelino Tallini, 171, Cx.P. 155, 95900-000, Lajeado, RS, Brasil; ajasper@univates.br

6 UFRGS, Instituto de Geociências, Av. Bento Gonçalves, 9500, Cx.P. 15001, 91501-970, Porto Alegre, RS, Brasil; rualdo.menegat@ufrgs.br

7 Companhia de Pesquisa de Recursos Minerais, Av. Dr. Freitas, 3645, 66095-110, Belém, PA, Brasil. margaws@yahoo.com.br 


\section{Keywords - Ash fall; Tonstein bed; Faxinal coalfield (Sakmarian); Gondwana; Early Permian}

Resumo - A integração de estudos de natureza petrográfica, paleobotânica e de matéria orgânica dispersa, associados a dataçôes radiométricas (Tuffzir 290.15 + 2.45/-0.85 $\mathrm{Ma}$ ) obtidas em camada de tonstein intercalada a uma camada de carvão na jazida de carvão de Faxinal (Sakmariano) no extremo sul da porção brasileira da bacia do Paraná, demonstrou que o processo muito rápido de deposição da cinza vulcânica é um fator a ser eminentemente considerado na interpretação da composição, tafonomia e consequentes peculiaridades na preservação da materia orgânica identificada nos diferentes estágios de deposição de uma associação de plantas em ambiente de floresta.

Palavras-chave - Queda de cinzas; Camada de tonstein; Jazida de carvão de Faxinal (Sakmariano); Gondwana; Início do Pérmico

\section{1 - Introduction}

Tonsteins are altered volcanic ash beds (BOHOR \& TRIPLEHORN, 1993) restricted to coal sequences which are excellent time markers for stratigraphic and basin analyses. In the last decade, some studies have been developed in tonstein beds from the southern Paraná basin (Brazil), with basis on radiometric dating of zircons (IDTIMS \& SHRIMP methods) and a consistent geochronological correlation was provided for regional coal seams in southern Brazil coalfields (MATOS et al., 2000; GUERRA-SOMMER et al., 2008a,b; MORI, et al., 2012).

The good preservation of the organic matter within the ash fall bed from the Faxinal Coalfield contributed to the development of studies with different approaches. This kind of "instantaneous geological event"(PROTHERO, 1990) played an important role in the plant preservation taking into account that the rapid inclusion of both, microscopic elements of terrestrial, parautochthonous and also autochtonous algal-like elements in fallen ash, are important to obtain paleoecological data.

The main goal of the present paper is to present the integration of different approaches from several published studies, which contributed for the reconstruction of the paleoecologic conditions during the volcanic ash fall. Evidences about the supposed thermally altered conditions of the preserved organic matter, caused by the volcanic ash fallen dynamic process are also highlighted.

\section{$2-$ Geological setting}

The Paraná basin is an intracratonic basin covering part $\left(1,700,000 \mathrm{~km}^{2}\right)$ of southern Brazil, Paraguay, Uruguay and Argentina (Fig. 1). MILANI et al. (2007) identified six supersequences stratigraphically ascendant, from Ordovician to Late Cretaceous (Fig. 1).

The Gondwana I Supersequence (Carboniferous/Early Triassic) includes the main coalfields (e.g. Faxinal), which are located in the southernmost basin border (Fig. 1). Coal deposits are related to paralic settings, i.e., adjacent to estuarine, deltaic, backshore, 
foreshore and shoreface siliciclastic sedimentary models, and that peat-forming was placed in back-barrier environments (ALVES \& ADE, 1996; HOLZ, 1998).

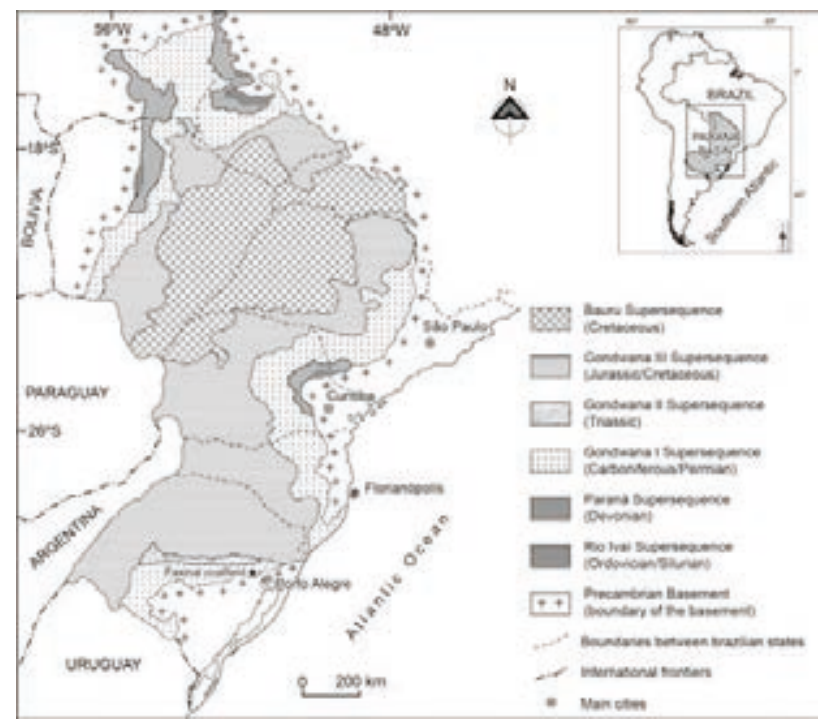

Fig. 1 - Simplified geological map of the Paraná Basin in Brazil with major tectonic elements, geographic references and location of Faxinal Coalfield (after SANTOS et al., 2006).

The Faxinal succession includes five coal seams, named from base to top I, IM, M, MS, and S (Fig. 2). The present study focused on a light gray claystone bed, approximately $10 \mathrm{~cm}$ thick, that is laminated to massive, fossiliferous and interbedded within the upper coal seam (S).

\section{3 - Mineralogy and petrology}

This tonstein (mean thickness of $8 \mathrm{~cm}$ ) is composed of primary minerals derived from volcanic ash and dust fall, and by secondary minerals formed during the diagenetic processes. This rock is composed of $90 \%$ authigenic kaolinite relicts of pyroclastic minerals occuring in the kaolinitic mass and corresponds to (1) euhedral bipyramidal $\beta$-quartz paramorph and transparent quartz splinters, (2) idiomorphic zircon, (3) euhedral apatite, and (4) sanidine pseudomorph. The granulometry of the zircons, $\beta$-quartz and apatite varies around 30 to $150 \mu \mathrm{m}$. Other diagenetic minerals were formed after the kaolinization of volcanic glass and some of the pyroclastic minerals from the ash fall. The diagenetic phases were established in the sequence: kaolinite-pyrite-siderite-calcite. Small color differences along the tonstein profile allowed the identification of three levels in the hand samples: basal level (carbonatic), intermediate level (siderite and pyrite), and top level (kaolinite). Their color distinction was attributed to variation in the mineralogical composition) by mineral phases produced during diagenesis (GUERRA-SOMMER et al., 2008a). Details in Fig. 3. 


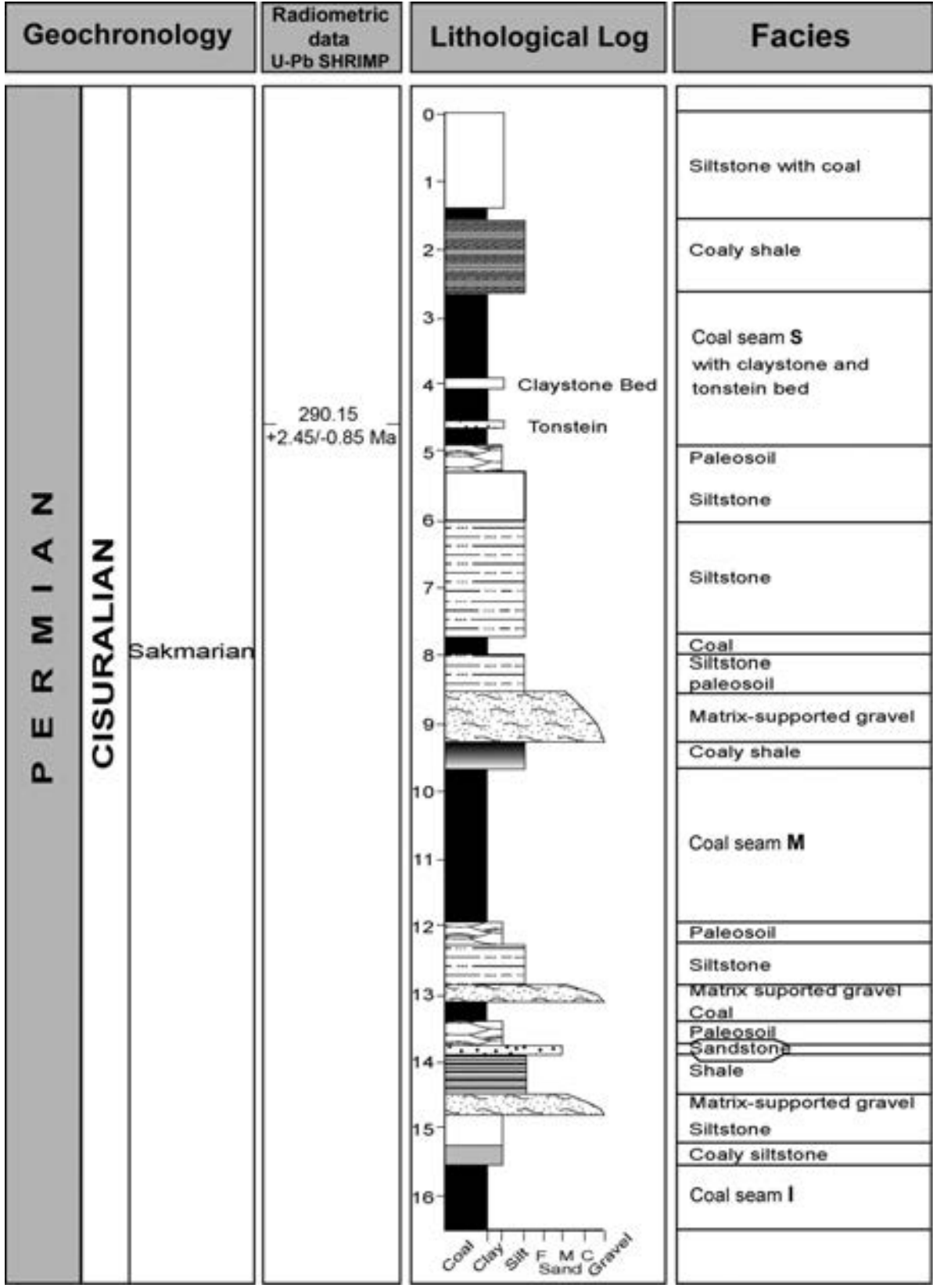

Fig. 2 - Geochronology, radiometric data, lithological log and facies of the Faxinal Coalfield (after GUERRA-SOMMER et al., 2008a). 

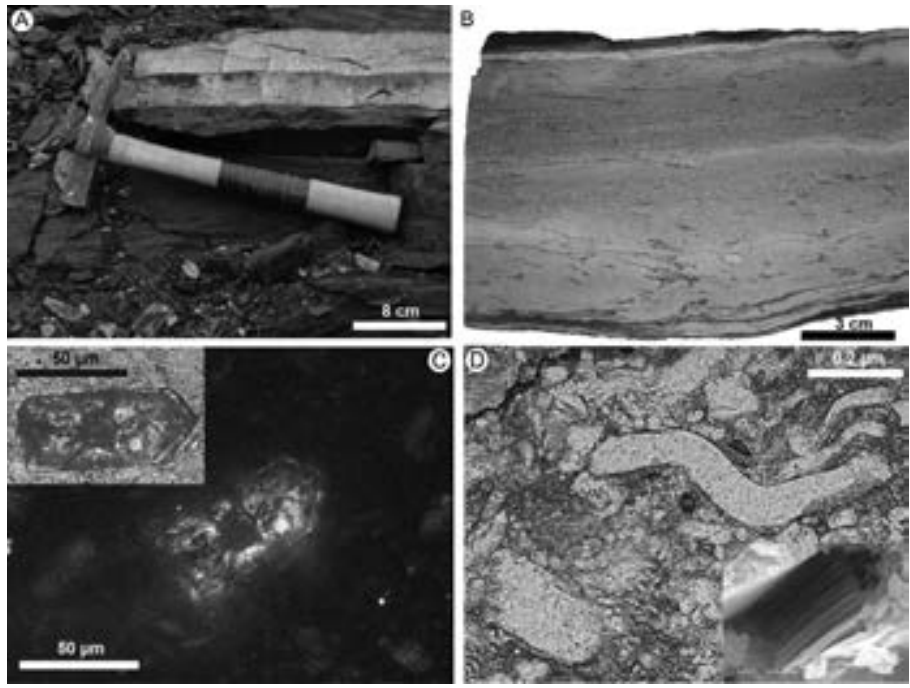

Fig. 3 - Tonstein of the Faxinal Coalfield. A. Tonstein interbedded in the coal seam S; B) tonstein profile showing the pronounced color differences produced by diagenetic mineral phases; C-D. Photomicrographs of thin sections showing pyroclastic minerals from the Faxinal tonstein; C. Idiomorphic zoned zircon with crystal bipyramidal termination; D. Kaolinite in elongate vermicular stacks and in the right lower corner SEM image showing "booklets" of kaolinite.

\section{4 - Geochronological significance of radiometric dating}

A radiometric conventional U-Pb dating (IDTIMS) from zircons of the tonstein layer indicate an age of $285.4 \pm 8.6 \mathrm{Ma}$ (GUERRA-SOMMER et al., 2008a). As this conventional $\mathrm{U}-\mathrm{Pb}$ zircon ages provided a relatively large uncertainty (of $8.5 \mathrm{Ma}$ the case of Faxinal), GUERRA-SOMMER et al. (2008b) performed SHRIMP U-Pb dating on zircons from tonstein samples at Candiota and Faxinal Coafield. The authors obtained Tuffzir age of $290.15+2.45 /-0.85 \mathrm{Ma}$ for the Faxinal tonstein and a mean age of $290.6 \pm 1.5 \mathrm{Ma}$ which is more precise than the previously published results.

\section{5 - Plant remains}

The rich parautochthonous compression of taphoflora hosted by the Faxinal tonstein is predominantly composed by fragments of glossopterid leaves (62\%) (Glossopteris brasiliensis, G. papillosa, G. similis-intermittens); cordaitalean leaves (Rufloria gondwanensis) represent $21 \%$ of the paleoflora; reproductive structures (Plumsteadia sennes, Scutum sp) and seeds (Platycardia sp.) correspond to $16 \%$ of the association; and fronds (Sphenopteris cf. ischanovensis, pecopterid fronds) are complementary forms (1\%). The top horizon is characterized by the abundance of highly compressed stems of gymnosperms (Aghatoxylon type) horizontally disposed (GUERRA-SOMMER et al., 2008a). The preservation of 
strongly horizontally compressed branches with Glossopteris (Fig. 4B) and Cordaites leaves still attached is a common features but the plant litter is poorly represented.

The stomatal density and index in compressed leaves of Glossopteris communis (Fig. 4A) at the Faxinal coalfield (Sakmarian) were low, when compared to the higher ones obtained in leaves from a younger interval at the northern part of the basin (Figueira Coalfield, Artinskian) (DEGANI-SCHMIDT et al., 2011).

The presence of abrupt, non abraded edges in charcoal samples recovered from the tonstein bed (Aghatoxylon type of wood) was a common feature (Fig. 4C). Statistical analyses evidenced the reduction of charcoal occurrences toward the top of the ash fall layer (JASPER et al., 2011).

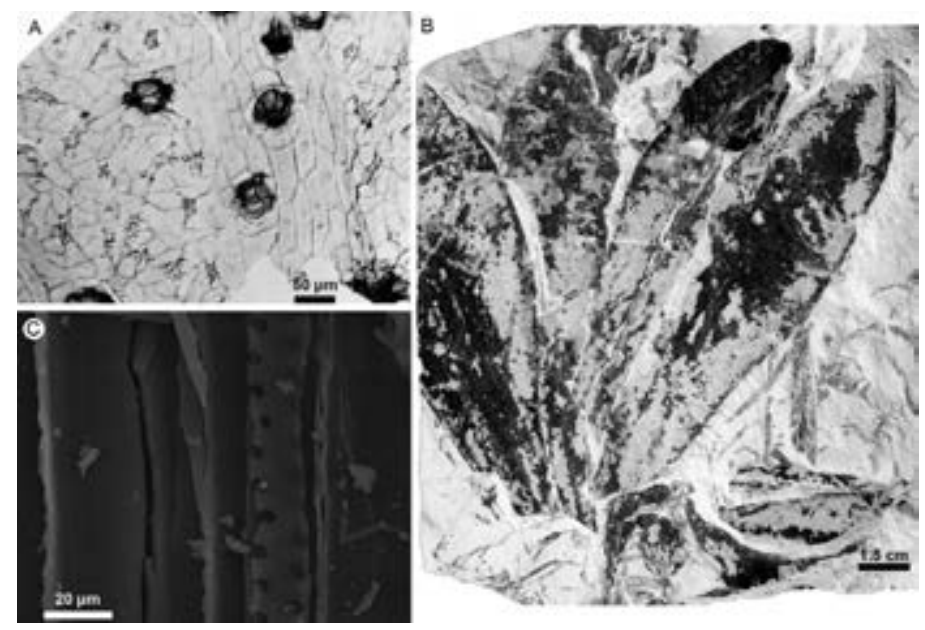

Fig. 4 - Plant remains from the tonstein bed of the Faxinal coalfield. A. Lower epidermis of Glossopteris leaf showing trichome bases and stomata; B. Leaf tuft of Glossopteris; C. Gymnosperm charcoal similar to the Aghatoxylon wood type.

\section{6-Microscopic organic matter}

Quantitative analyses of kerogens were developed for the basal, intermediate and top tonstein levels by SIMAS et al. (in press) and evidenced high percentages of the Structured Organic Matter (SOM) of the phytoclast group (arithmetic mean $91.14 \%$ ) combined with low percentages of the palynomorph group (arithmetic mean $8.86 \%$ ). Amorphous Organic Matter (AOM) group was not observed along the tonstein profile.

Palynomorphs vinculated to gymospermous terrestrial plants dominate over aquatic palynomorphs. Pollen clusters, mainly bissacate, are concentrated at the base of the tonstein bed. The occurrence of both terrestrial pteridophytic sporomorphs and aquatic Botryococcus colonies is rare, restricted to the tonstein top level.

Non-opaque xylem phytoclasts are proportionally dominant in relation to larger opaque angular xylem phytoclasts. Also opaque phytoclasts exhibit angular shapes and notable size. Isolated thin cuticles showing polygonal or rectangular cell outlines are 
represented along the entire profile, some of them with typical glossopterid trichomes. Well preserved fragments with upper and lower cuticles stuck together, in single fragments are common phytoclasts along the tonstein profile. A weak fluorescence was observed in several cuticular phytoclasts.
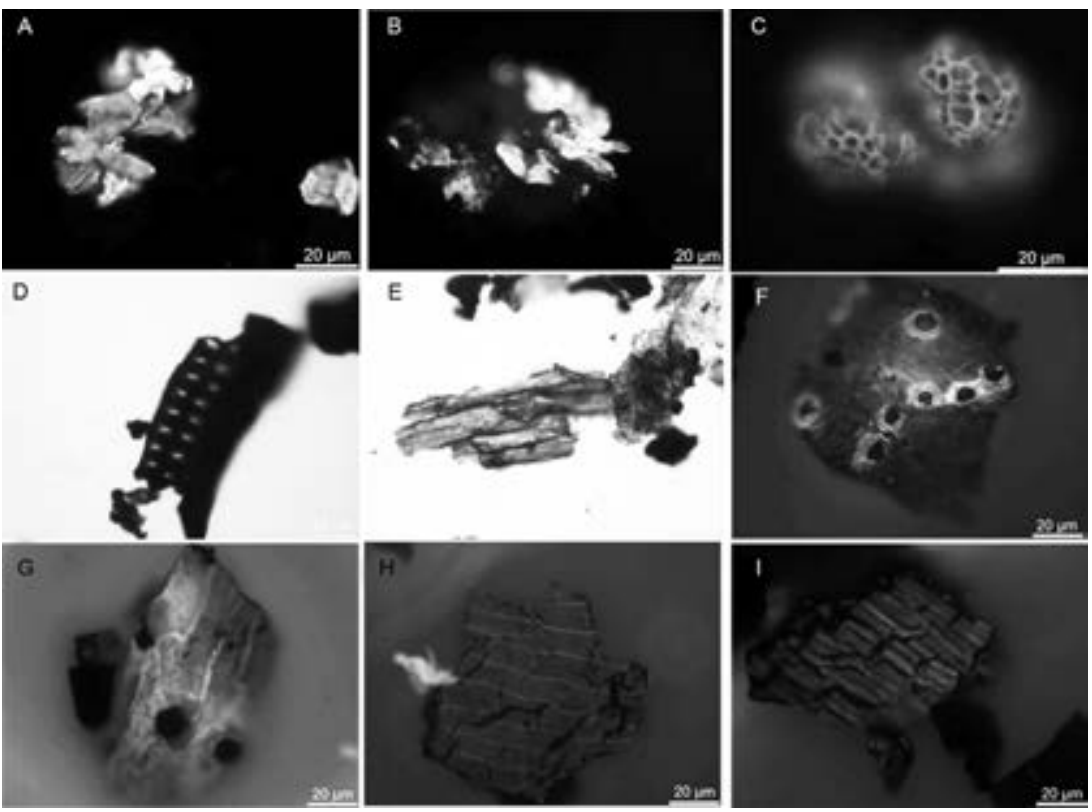

Fig. 5 - Palynological organic matter of the tonstein bed in the Faxinal coalfield. Photos taken in fluorescent light. A-C. Palynomorph group; A-B. Amalgamated and poorly preserved bisaccate pollen grains; C. Botryococcus colonies; D-I. Phytoclast group; D. Gymnosperm tracheid with bordered pits; E. Isolated thin cuticle; F-G. Lower epidermis of Glossopteris typical from Faxinal tonstein, showing typical trichome bases; H-I. Upper and lower cuticles stuck together (upper surface view showing rectangular shaped cells).

\section{7 - Final considerations}

The integration of different approaches, besides offering new geochronologic data $(290.6 \pm 1.5 \mathrm{Ma})$ to the geological conception model of coal succession in the southern Paraná basin (constrained to the Middle Sakmarian), contributed for the reconstruction of the paleoecologic conditions prevalent during the volcanic ash fall in the Faxinal Coalfield.

Petrography and mineralogical analyzes along three different levels of the tonstein bed did not evidence any difference in the depositional processes, suggesting a single volcanic event.

Leaf fragments horizontally disposed indicate an episodic, uncommon fall of plant material. This is an evidence of volcanic activity in both modern environments (BURNHAM \& 
SPICER, 1986) and also in Permian scenarios (PFEFFERKORN \& WANG, 2007). This peculiar feature was explained by the rapid ash fall deposition process causing the blockage of leaf stomata and dislodged leaves, which become incorporated in the ash fall deposits.

Considering the palynomorph group, the dominance of pollen grains along the tonstein profile and the occurrence of spores restricted to the top level confirm the selective deposition process, which was related to the stratification of canopy. Additionally, the large amounts of mature pollen grains preserved as dense clusters incorporated in ash fall deposits, suggested that parental plants growing nearby were supplying the pollen grains. On the same way, the well-preserved phytoclasts with upper and lower foliar cuticles stuck together indicate that the rapid fall of ash on this material hindered organic biodegradation. The peculiar process of ash deposition, which prevented oxidation and minimal sorting, led to the uncommon dominance of non-opaque over opaque xylem phytoclasts.

The subaqueous ash deposition, evidenced by the presence of seemingly autochthonous Botryococcus colonies would protect thin volcanic ash deposits from subsequent redistribution by rainfall and surface runoff. The weak fluorescence in cuticles and darkening of xylem phytoclasts can be attributed to different causes, but probably mainly to the thermal influence of ash fall during deposition or chemical effects of the ash. The reduction of charcoal occurrences toward the top of the ash fall layer was connected to the intensity of the fire at the beginning of the ash fall.

Stomatal density and index in compressed leaves of Glossopteris could be related to a temporary increase in $\mathrm{CO}_{2}$ levels (during a phase of reduction global trend of this atmospheric gas), due to the more extensive areas of peat accumulation at the southern part of the basin, and/or under intense ash fall due to volcanic activities. On the other hand, the absence of AOM, as occurs in the Faxinal tonstein, has been reported in coals and allied sedimentary facies deposited in anoxic reducing paleoenvironments influenced by freshwater environments (TYSON, 1995).

\section{References}

ALVES, R. G. \& ADE, M. V. B. (1996) - Sequence stratigraphy and organic petrography applied to the study of Candiota coalfield, RS, South Brazil. International Journal of Coal Geology, 30, p. 231-248.

BOHOR, B. F. \& TRIPLEHORN, D. M. (1993) - Tonsteins: Altered Volcanic-Ash Layers in Coal-bearing Sequences. Special Paper of Geological Society of America, 285, 42 p.

BURNHAM R. J. \& SPICER, R. A. (1986) - Forest litter preserved by volcanic activity at El Chichon, Mexico; a potentially accurate record of the pre-eruption vegetation Palaios, 1, p. 158-161.

DEGANI-SCHMIDT, I., GUERRA-SOMMER, M. \& BERNARDES-DE-OLIVEIRA, M. E. C. (2011) - Variation in stomatal numbers of Glossopteris leaves from the Lower Permian of Paraná Basin (Brazil). Revista Brasileira de Paleontologia, 14, p. 137-148.

GUERRA-SOMMER, M., CAZZULO-KLEPZIG, M., FORMOSO, M. L. L., MENEGAT, R. \& MENDONÇA FILHO, J. G. (2008a) - U-Pb dating of tonstein layers from a coal succession of the southern Paraná Basin (Brazil): A new geochronological approach. Gondwana Research, 14, p. 474-482.

GUERRA-SOMMER, M., CAZZULO-KLEPZIG, M., SANTOS, J. O. S., HARTMANN, L. A., KETZER, J. M. M. \& FORMOSO, M. L. L. (2008b) - Radiometric age determination of tonsteins and stratigraphic constraints for the Lower Permian coal succession in southern Paraná Basin, Brazil. International Journal of Coal Geology, 74, p. 13-27. 
HOLZ, M. (1998) - The Eopermian coal seams of the Paraná Basin in southernmost Brazil: an analysis of the depositional conditions using sequence stratigraphy concepts. International Journal of Coal Geology, 36, p. 141-163.

JASPER, A., UHL, D., GUERRA-SOMMER, M., HAMAD, A. M. B. A. \& MACHADO, N. T. G. (2011) - Charcoal remains from a tonstein layer in the Faxinal Coalfield, Lower Permian, southern Paraná Basin, Brazil. Anais da Academia Brasileira de Ciências, 83, p. 471-481.

MATOS, S. L. F., YAMAMOTO, J. K., HACHIRO, J. \& COIMBRA, A.M. (2000) - Tonsteins da Formação Rio Bonito no depósito de carvão de Candiota, RS. Revista Brasileira de Geociências, 30, p. 679-684.

MilAni, E. J., MElO, J. H. G., SOUZA, P. A, FERNANDES, L. A. \& FRANÇA, A. B. (2007). Bacia do Paraná. Boletim de Geociências da Petrobrás, 15, p. 265-287.

MORI, A. L. O., SOUZA, P. A., MARQUES, J. C. \& LOPES, R. C. (2012) - A new U-Pb zircon age dating and palynological data from a Lower Permian section of the southernmost Paraná Basin, Brazil: Biochronostratigraphical and geochronological implications for Gondwanan correlations. Gondwana Research, 21 (2-3), p. 654-669.

PFEFFERKORN, H. W. \& WANG, J. (2007) - Early Permian coal-forming floras preserved as compressions from the Wuda District (Inner Mongolia, China). International Journal of Coal Geology, 69, p. 90-102.

PROTHERO, D. R. (1990) - Interpreting the stratigraphic record. W.H. Freeman \& Co., New York, 410 p.

SANTOS, R. V., SOUZA, P. A., ALVARENGA, C. J. S., DANTAS, E. L., PIMENTEL, M. M., OLIVEIRA, C. G. \& ARAÚJO, L. M. (2006) - Shrimp U-Pb zircon dating and palynology of bentonitic layers from the Permian Irati Formation, Paraná Basin, Brazil. Gondwana Research, 9, p. 456-463.

SIMAS, M. W., GUERRA-SOMMER, M., MENDONÇA FILHO, J. G., CAZZULO-KLEPZIG, M., FORMOSO, M. L. L., BASEI, M. A. S. \& DEGANI-SCHMIDT, I. (in press) - An accurate record of volcanic ash fall deposition as characterized by dispersed organic matter in a Lower Permian tonstein bed (Faxinal Coalfield, Paraná Basin, Brazil). Geologica Acta.

TYSON, R. V. (1995) - Sedimentary organic matter: Organic facies and palynofacies: Organic facies and palynofacies. London, Chapman \& Hall, 615p. 